\title{
TEORI KONFLIK DIALEKTIKA RALF DAHRENDORF
}

\author{
Yogi Prana Izza, Lc., MA \\ Institut Agama Islam (IAI) Sunan Giri Bojonegoro \\ Email: zherifzizi@gmail.com
}

\begin{abstract}
This paper focuses on discussing how to structure society according to Dahrendorf, how he built his theory; from where the building theory came from, and what new thesis Daherendorf produced. Dahrendorf sees social reality as having two faces (conflict and consensus). Therefore, the theory of sociology is divided into two parts; conflict theory and consensus theory. Here it is seen that Daherndorf in theory tried to perfect Marx and Weber's opinions on social reality. The final aspect of Dahrendorf's conflict theory is the link between conflict and social change. Conflict, according to him, leads to change and development. In conflict situations, the groups involved take actions that make changes in the social structure
\end{abstract}

Keyword: conflict theory, Dialectica, Ralf Dahrendorf

\section{A.Pendahuluan}

Teori konflik secara umum merupakan anti tesis dari teori fungsionalisme yang melihat perkembangan dan perubahan sosial bersifat statis. Struktur sosial menurut teori konflik tidak berwajah statis melainkan dinamis atau dialektis. Secara spesifik, teori konflik dialektika yang dikemukakan oleh Dahrendorf adalah sanggahan terhadap pandangan-pandangan Parsons dan terhadap teori struktural fungsional secara keseluruhan (Turner, 1974: 92). Bagi Dahrendorf, apa yang dirumuskan oleh Parsons dan pengikutnya tentang tatanan masyarakat hanyalah menampilkan wajah baik saja, tetapi melupakan wajah buruk (ugly face) masyarakat.

Untuk membangun teorinya, Dahrendorf melakukan kombinasi atau modifikasi dari teoriteori konflik yang ada, lebih khususnya mengambil model dari teori konflik Karl Max dan Marx Weber. Pemikiran dua tokoh penggerak teori konflik ini dikaji secara mendalam oleh Dahrendorf lalu secara cerdik dijadikan pijakan melalui separuh penerimaan dan separuh penolakan.

Namun demikian, Dahrendorf juga terjebak dalam kungkungan teori struktural fungsional yang dikritiknya secara tajam. Fokus perhatian kajiannya terkait dengan otoritas, posisi, asosiasi yang dikoordinir secara imperativ (ICA), kepentingan, kelompok semu, kelompok kepentingan, dan kelompok konflik, adalah term-term yang menurut para sosiolog berdekatan dengan fungsionalisme struktural. 
Itulah diantara sebab mengapa para Sosiolog seperti Turner, Goerge Ritzer, Douglas J. Goodman dan deretan sosiolog lainnya mengalisis bahwa teori konflik dialektika Dahrendorf memiliki banyak kekurangan. Namun dibalik kekurangan-kekurangan itu, Dahrendorf telah melahirkan kritik penting terhadap pendekatan yang pernah dominan dalam sosiologi yang dianggap telah gagal menganalisa konflik sosial.

Makalah ini akan difokuskan pada pembahasan bagaimana struktur masyarakat menurut Dahrendorf, bagaimana ia membangun teorinya; dari mana sumber bangunan teorinya, dan tesis baru apa yang dihasilkan Daherendorf.

\section{B.Keteraturan Sosial (Social Order) Menurut Dahrendorf}

Istilah tertib sosial atau keteraturan sosial (social order) sebenarnya terminologi yang digunakan oleh fungsionalisme struktural. Kondisi keteraturan sosial (social order) ditandai dengan adanya kohesi sosial dan stabilitas yang dalam hal ini diartikan sebagai kondisi koordinasi dan pemeliharaan hubungan antara unit-unit sistem dengan mekanisme konsesus yang diikat secara normatif (Mudji\&Putranto, 2005: 71).

Lebih lanjut, Parsons menjelaskan bahwa untuk mencapai tertib sosial dalam suatu masyarakat yang kompetitif diperlukan dua mekanisme utama, yaitu mekanisme pengendalian sosial oleh norma-norma dan mekanisme sosialisasi. Kedua mekanisme ini yang mengatur kepribadian perorangan yang kompetitif untuk mencapai suatu konsesus (Soekanto, 1990: 112113).

Parsons mengartikan mekanisme pengendalian sosial sebagai cara dimana berbagai peranan sosial diorganisasikan dalam sistem-sistem sosial untuk mengurangi tekanan atau penyimpangan, dimana bisa diartikan sebagai peraturan atau sanksi-sanksi. Sedangkan mekanisme sosialisasi diartikan sebagai sarana pembudayaan nilai-nilai, kepercayaan, bahasa, dan simbol lainnya yang diinternalisasikan ke dalama sistem kepribadian yang dapat memenuhi harapan dan kebutuhannya. Dengan adanya sosialisasi, masing-masing kepribadian dapat menjalankan peranannya sehingga menjamin integrasi suatu sistem sosial (Soekanto, 1990: 113).

Maka, social order dalam istilah dan pandangan fungsionalisme struktural adalah kondisi damai atau kondisi harmonis dengan keseimbangan (equilibrium) dimana semua unsur sosial mencapai konsesus (kesepakatan) dengan cara menekan semaksimal mungkin munculnya sebuah konflik atau pertentangan dimasyarakat. 
Tetapi dalam teori-teori konflik, khususnya dalam pandangan Daherndorf, konflik tidak membuat "sosial disorder" karena hakekatnya konflik dipandang suatu hal yang inheren dalam masyarakat. Konflik dipandang sebagai bentuk interaksi sosial. Konflik tidak dipandang sebagai suatu kondisi disfungsional bagi sistem sosial. Dalam perspektif Teori Konflik, keseimbangan atau kedamaian adalah kondisi dipertemukannya berbagai pertentangan atau kepentingan yang berbeda dalam suatu sistem relasi yang baru.

Sehingga kondisi tertib sosial tidak diartikan dan dihasilkan dari meredam, menekan atau meniadakan konflik, melainkan sebagai suatu kondisi sintesa, dimana konflik bisa dikelola dengan baik dan ditransformasikan dalam bentuk yang kondusif bagi kehidupan manusia, sehingga menjadi konflik konstruktif yang bersifat fungsional (Lauer,2001: 98). Tapi bagaimana konflik yang melekat pada masyarakat, tidak menjadikan disfungsi sistem, atau sistem masih tetap berjalan $?$.

Jawaban dari pertanyaan diatas adalah karena kepentingan-kepentingan anggota masyarakat sudah terwakili melalui mekanisme yang "terlembaga" sehingga menghasilkan kompromikompromi baru yang diterima. Daherndorf menyebutnya sebagai "asosiasi yang ditata berdasarkan perintah" (Impetaratively Coordinated Associations/ICA) yang mewakili organisasi-organisasi yang berperan penting di dalam masyarakat (Turner,1974: 93).

\section{ICA : Otoritas, Posisi dan Kepentingan}

ICA atau asosisasi yang ditata berdasarkan perintah, sebenarnya berasal dari argumen Dahrendorf yang menyatakan bahwa masyarakat terdiri dari sejumlah unit. Unit-unit ini adalah asosiasi orang yang dikendalikan oleh hierarki otoritas. Otoritas tidak terletak dalam diri individu tetapi dalam posisi. Karena terletak dalam posisi, otoritas tidak konstan. Artinya, seseorang yang berwenang dalam satu lingkungan tertentu tak harus memegang poisisi otoritas didalam lingkungan lain (Ritzer,1996: 267).

Otoritas yang melekat pada posisi adalah unsur kunci dalam analisis Dahrendorf. Otoritas secara jelas menyatakan adanya superordinasi (berkuasa) dan subordinasi (yang dikuasai/bawahan). Karena masyarakat terdiri dari berbagai posisi, seorang individu dapat menempati posisi otoritas di satu unit dan menempati posisi yang subordinat di unit yang lain.

Mereka yang menduduki posisi otoritas atau kekuasaan diharapkan akan mengendalikan bawahan. Artinya, mereka berkuasa karena harapan dari orang yang berada disekitar mereka, 
bukan karena ciri-ciri psikologis mereka sendiri. Seperti otoritas, harapan ini pun melekat pada posisi, bukan pada orangnya. Hal ini menunjukkan adanya faktor "paksaan" oleh suatu kelompok atas kelompok yang lain. Dalam ICA hubungan kekuasaan menjadi “tersahkan" atau terlegitimasi. Maka sanksi dapat diberikan kepada masyarakat yang tidak mematuhinya (Ritzer, 1996: 267). Dalam pandangan teori Konflik Dialektika: Kekuasaan (power) dan Otoritas (authority) merupakan sumber yang langka dan selalu diperebutkan dalam sebuah ICA.

Tidak dapat disangkal bahwa antara superordinasi dengan subordinasi terdapat pertentangan atau konflik. Kekuasaan selalu memisahkan dengan tegas antara penguasa dan yang dikuasai maka dalam masyarakat selalu terdapat dua golongan yang saling bertentangan. Mereka yang berada pada posisi dominan berusaha mempertahankan status quo sementara yang berada pada subordinat berusaha melakukan perubahan.

Konflik yang niscaya ada ini dapat diatasi oleh kekuasaan yang dihimpun di dalam ICA. Bagi Dahrendorf, konflik hanya muncul melalui relasi-relasi sosial dalam sistem. Setiap individu atau kelompok yang tidak terhubung dalam sistem tidak akan mungkin terlibat dalam konflik (Susan,2009: 55). ICA adalah "tempat" yang dominan dapat meredam konflik. Dalam tinjauan Konflik Dialektika, suatu kepentingan bisa dinegoisasikan antar kelompok dalam ICA, jika sudah menjadi "kelompok kepentingan" yang bersifat riil. Sehingga, bersatunya individu yang memiliki kepentingan yang sama dalam sebuah kelompok yang terorganisir menjadi hal yang penting.

Disinilah terdapat konsep lain yang menjadi kunci dari teori konflik dialektika Dahrendorf yang disebut dengan kepentingan (interests). Kelompok yang berada diatas dan berada dibawah didefinisikan berdasarkan kepentingan bersama. Dahrendorf tetap menyatakan bahwa kepentingan itu, yang seperti tampak sebagai fenomena psikologi, pada dasarnya merupakan fenomena berskala luas (Ritzer,1996: 267). Pertentangan kepentingan ini selalu ada setiap waktu dan setiap struktur. Karena itu, kekuasaan yang sah selalu berada dalam keadaan terancam bahaya dari golongan yang anti status quo.

Kepentingan yang terpadat pada satu golongan tertentu dinilai obyektif oleh golongan yang bersangkutan dan selalu koheren dengan posisi individu yang termasuk dalam golongan itu. Seorang individu akan bersikap dan bertindak sesuai dengan cara yang berlaku dan yang diharapkan oleh golongannya. Dalam situasi konflik seorang individu akan menyesuaikan diri dengan peranan yang diharapkan oleh golongannya itu, yang oleh Dahrendorf disebut sebagai peranan laten (Nasir,2009: 25). 
Oleh karena itu, kepentingan yang sama dari beberapa individu, jika tidak diorganisasi secara formal kedalam suatu kelompok, merupakan "kepentingan semu", karena tidak ada yang bisa mewakili atau mengatasnamakan pemilik kepentingan.

\section{Kelompok Semu, Kelompok Kepentingan dan Kelompok Konflik}

Dahrendorf membedakan tiga tipe utama kelompok. Pertama adalah kelompok semu atau" sejumlah orang pemegang posisi dengan kepentingan sama”. Kelompok semu ini adalah calon tipe kedua yakni kelompok kepentingan, dan dari berbagai kelompok kepentingan ini, muncul kelompok konflik. Atau kelompok yang terlibat dalam konflik kelompok aktual. Hubungan antara kelompok semu dan kelompok kepentingan dinyatakan Dahrendorf, sebagaimana dikutip Ritzer (1996: 268) adalah sebagai berikut:

Model perilaku yang sama adalah karakteristik dari kelompok kepentingan yang direkrut dari kelompok semu yang lebih besar. Kelompok kepentingan adalah kelompok dalam pengertian sosiologi yang ketat; dan kelompok ini adalah agen riil dari konflik kelompok. Kelompok ini mempunyai struktur,bentuk organisasi,tujuan atau program dan anggota perorangan

Menurutnya, ketiga kelompok tersebut (kelompok semu, kelompok kepentingan dan kelompok konflik) mempunyai kepentingan yang berbeda-beda, namun berpengaruh dalam perubahan struktural dalam masyarakat (Ritzer,1996: 268).

Kepentingan kelas objektif yang ditentukan secara struktural yang tidak disadari oleh individu disebut Dahrendorf dengan kepentingan laten (latent interest), dimana kepentingan itu tidak dapat menjadi dasar yang jelas dalam pembentukan kelompok. Para anggota didalam asosiasi yang dikoordinasi secara imperatif itu memiliki kepentingan laten yang sama dapat dipandang sebagai kelompok semu (quasi group). Sebaliknya, kepentingan kelas yang disadari individu terutama jika kepentingan itu secara sadar dikejar sebagai tujuan disebut sebagai kepentingan manifest (Raho,2007: 78).

Bagi asosiasi apa saja, ada dua kelompok semu yang utama, yaitu mereka yang memiliki posisi dominasi otoritatif dan mereka yang harus tunduk pada pengguna otoritas tersebut. Kalau orang dalam salah satu kelompok semu mengembangkan suatu kesadaran kelas bersama, kesadaran akan kepentingan bersama, dan mengorganisasikan kegitan untuk mengejar kepentingan itu, maka akan melahirkan suatu kelompok kepentingan. 
Meskipun para anggota suatu kelompok kepentingan yang bersifat konflik diambil dari kelompok semu yang sama, tidak smua orang yang termasuk dalam kelompok semu yang sama itu harus bergabung dalam suatu kelompok kepentingan yang bersifat konflik untuk mengejar kepentingan kelasnya (Ritzer, 1996: 268).

Didalam kelompok kepentingan itu juga terdapat "kelompok-kelompok kepentingan antagonis" yang juga dikaji oleh Ralf Dahrendorf. Sebagaiman dikutip oleh Hakimul Ikhwan Affandi (2004: 146-147), ia mengatakan :

Hendaknya dibedakan dua meta teori,pertama menggambarkan bahwa sistem sosial itu terintegrasi secara fungsional dan menyumbangkan suatu nilai yang mendasar perannya dalam mempertahankan sistem keseimbangan.Kedua , memandang bahwa struktur sosial itu merupakan suatu bentuk organisasi yang dijalankan bersama-sama melalui tekanan dan paksaan secara terus-menerus sehingga akhirnya melampaui dirinya sendiri dengan suatu pengertian bahwa dalam tekanan itu sendiri akan melahirkan ketahana dengan proses perubahan yang tiada henti-hentinya.

Dalam uraiannya tentang kelompok-kelompok kepentingan yang antagonis, Dahrendorf membuat destingsi antara kelompok potensial dengan kelompok aktual. Kalau sejumlah orang mempunyai kepentingan bersama,apakah kepentingan itu disadari atau tidak disadari, namun mereka belum berorganisasi dan bersatu, maka mereka disebut kelompok konflik potensial.Mereka mempunyai kemungkinan (potensi) untuk menjadi kelompok aktual,tetapi untuk sementara waktu hanya benihnya saja ada.

Pada intinya, Dahrendorf berpendapat bahwa konsep-konsep seperti kepentingan nyata dan kepentingan laten, kelompok kepentingan dan kelompok semu, posisi dan otoritas merupakan unsur-unsur dasar untuk dapat menerangkan bentuk-bentuk konflik (Ritzer,2010: 27). Menurutnya, konfilk itu dapat dibedakan atas empat macam, yaitu sebagi berikut (Lauer,2001: 102) :

1. Konflik antara atau yang terjadi dalam peranan sosial, atau bisa disebut sebagai konflik peran. Konflik peran adalah suatu keadaan dimana individu menghadapi harapan-harapan yang berlawanan dari bermacam-macam peranan yang dimilikinya.

2. Konflik antara kelompok-kelompok sosial.

3. Konflik antara kelompok-kelompok yang terorganisir dan tidak teroganisir. 


\section{Yogi Prana Izza, Lc., MA}

4. Konflik antara satuan nasional, seperti antar partai politik, antar negara atau organisasi sosial.

\section{Sumber Bangunan Teori Konflik Dialektika Dahrendorf}

Munculnya teori konflik dialektika Dahrendrof pada dasarnya berasal dari kritik atas teori Struktural Fungsional secara umum, dan kritik terhadap Parsonian secara khusus. Namun model teori konflik dialektika Dahrendorf adalah juga "sumbangan" dari model teori Konfliknya Marx dan Weber.

Dahrendorf tidak menolak dan tidak juga menerima semua teori Karl Max, demikian juga Weber, separuh diterima dan dimodifikasi sebagai bangunan dari teori Konflik Dialektikanya. Karena menurutnya, penolakan terhadap teori-teori lama tidak akan bermanfaat jika tidak menjadi titik tolak bagi perumusan teori-teori baru (Poloma, 2013: 130\&133).

\section{Kritik terhadap Parsonian (Struktural Fungsional)}

Kritik Dahrendorf terhadap pandangan Parsonian atau teori struktural fungsional sudah dimulai sejak tahun 1958. Skema AGIL (Adaptation, Goal attainment, Intergration, Latency) yang menjadi basis teori struktural fungsional disebut Dahrendorf sebagai suatu yang "utopis". Karena hakekatnya masyarakat mempunyai "dua wajah” yang bersifat konflik (conflict) dan konsensual (consensus) (Turner,1974: 92).

Dahrendorf menolak teori fungsionalisme Struktural yang lebih menekankan kepada konsensus dalam sistem masyarakat secara berlebihan. Seluruh elemen menciptakan konsensus dan keteraturan sosial serta keseluruhan elemen saling beradaptasi dengan baik terhadap perubahan internal dan eksternal dari masyarakat (Soekanto,1990: 330). Meski mengkritik konsensus, sebenarnya Daherndorf tidak berupaya menggantikan teori konsensus, justru ia menggunakan konsep yang sama, tetapi dengan cara yang berberlawanan. Karena setiap unsur sosial mempunyai satu fungsi, konsensus dan paksaan yang berdampingan (Craib, 1992: 92).

Untuk melepaskan diri dari kungkungan utopia itu, Dahrendorf menawarkan suatu model teori konflik sebagai substansi model teori struktural fungsional. Model yang lahir dari sudut pandang ini disebut sebagai perspektif konflik dialektika dan dianggap lebih sesuai dengan apa yang berlaku di dunia dibanding teori struktural fungsional.

Dalam Essay of The Theory of Society, Dahrendorf (1968: 128) memberikan saran agar terlepas dari kungkungan utopia : 
Concentrate in the future not only on concrete problems but on such problems as involve explanations in terms of constraint, conflict, and change. This second face of society may be esthetically rather less pleasing than the first, but if all that sociology had to offer were an easy escape to utopian tranquillity, it would hardly be worth our efforts

(Berkonsentrasi terhadap masa depan tidak hanya pada masalah konkrit tetapi pada masalah yang melibatkan penjelasan dalam istilah-istilah dari kendala, konflik dan perubahan. Wajah kedua dari masyarakat ini secara estetika kurang menyenangkan dibandingkan dari wajah pertama. Akan tetapi jika seluruh sosiologi yang telah ditawarkan merupakan jalan mudah untuk lari kepada ketenangan utopia, maka ini hampir tidak sebanding dengan usaha kita).

Dari sini dapat dipahami, bagi teori konflik dialektika, masyarakat bergerak tidak dalam kondisi statis atau dalam keseimbangan seperti yang dikemukakan oleh teori fungsionalisme struktural. Tetapi, masyarakat senantiasa bergerak dalam proses perubahan yang ditandai dengan adanya konflik atau pertentangan yang terus menerus diantara unsur-unsurnya.

Namun bagi teori struktural fungsional, unsur-unsur atau elemen pada struktur masyarakat saling memberikan dukungan terhadap stabilitas. Karena setiap elemen, sebagaimana teori Parsons, bersifat integratif dalam suatu sistem. Sehingga kalaupun ada perubahan, maka bersifat teratur (statis) (Poloma, 2013: 171-172).

Kritik Dahrendorf lainnya terhadap teori Struktural fungsional adalah pandangan bahwa secara informal, anggota masyarakat terkait dengan norma-norma, nilai-nilai dan moralitas umum. Teori Konflik menilai keteraturan yang terdapat dalam masyarakat itu hanyalah disebabkan adanya pemaksaan kekuasaan dari atas oleh golongan yang berkuasa (Ritzer, 2010: 26). Dengan kata lain, Dahrendorf melihat paksaan dan konflik sebagai inti bagi pemahaman struktur masyarakat (Poloma,2013: 141).

Secara umum, asumsi yang dipakai dalam mengembangkan teori sosial konflik adalah bertolak belakang dengan asumsi yang mendasari teori struktural-fungsionalisme (Megawangi, 1999: 43), yaitu :

a. Walaupun relasi sosial menggambarkan karakteristik yang sistemik, pola relasi yang ada sebenarnya penuh dengan kepentingan-kepentingan pribadi atau sekelompok orang. Hal ini membuktikan bahwa sistem sosial secara sistematis menghasilkan konflik. 
b. Maka konflik adalah suatu yang tak terhindarkan dalam semua sistem sosial. Konflik akan terjadi dalam aspek pendistribusian sumber daya yang terbatas, terutama kekuasaan.

c. Konflik adalah sumber utama terjadinya perubahan dalam masyarakat.

Secara singkat Ralf Dahrendorf menjelaskan point-point tentang teori fungsionalisme yang dikritik yaitu:

1. Masyarakat adalah elemen-elemen struktur yang berkembang relatif stabil.

2. Masyarakat adalah elemen-elemen struktur yang terintegrasi dengan baik

3. Setiap elemen masyarakat mempunyai fungsi yaitu menyebabkan suatu sumbangan terhadap ketahanan system.

4. Setiap fungsi struktural sosial didasarkan oleh konsensus nilai-nilai antar anggotaanggotanya.

Oleh karenanya, Dahrendorf menilai bahwa fungsionalisme struktural masih menggunakan teori yang konservatif dan sedikit sekali menjelaskan konflik. Padahal menurutnya, pendekatan konflik dapat memperjelas posisi masyarakat. Berikut hasil dari pendekatan konflik :

1. Masyarakat dalam setiap waktu diatur oleh beberapa perubahan sosial yang tidak dapat dihindari.

2. Masyarakat dalam setiap waktu menunjukan adanya konflik dan konsesus, kedua-duanya merupakan fenomena masyarakat yang tidak dapat dihindari.

3. Setiap anggota masyarakat akan memberikan adanya suatu sumbangan disintegrasi dan munculnya perubahan.

4. setiap masyarakat didasarkan atas tekanan para anggotanya oleh pihak lain.

\section{Marx dan Weber dalam Model Teori Konfik Dialektika Dahrendorf}

Tidak bisa dipungkiri bahwa teori Konflik Dialektika Dahrendorf memiliki benang merah yang jelas dengan model teori Konflik yang pernah dikemukakan para tokoh penggerak teori konflik ; yaitu Karl Marx, Marx Weber dan Goerg Simmel. Tetapi agaknya, teori Marx dan Weber, lebih khususnya Marx, lebih banyak mendapatkan perhatian (diadopsi dan ditolak) dibandingkan Simmel. 
Para motor penggerak teori konflik diatas, umumnya membangun teorinya melalui proposisi-proposisi yang berbeda-beda tentang kejadian konflik di masyarakat dari unit analisis yang berbeda pula. Setidaknya ada tiga komponen dasar sistem sosiokultural yang dijadikan para sosiolog dalam menganalisis kejadian-kejadian sosial ; superstruktur ideologis, struktur sosial, dan infrastruktur material.

Karl Marx dalam hal ini lebih cenderung menjadikan infrastruktur material sebagai unit analisisnya. Oleh karenanya Marx melihat bahwa konflik terjadi disebabkan karena timpangnya akses terhadap sumberdaya. Ketimpangan ini yang menciptakan kelompok-kelompok yang memposisikan sebagi supordinat (berkuasa) disatu sisi dan disisi yang lain adalah subordinat (termarjinalkan/dikuasai).

Sedangkan Marx Weber menjadikan superstruktur ideologis sebagai unit analisisnya. Hal ini bisa dilihat dari bangunan proposisi-proposisi yang dijadikan pijakan teorinya. Proses konflik antara superordinat dengan subordinat dapat terjadi menurut Weber disebabkan tarikan otoritas politik. Sedangkan tarikan otoritas politik terjadi melalui kelompok status dan juga ketimpangan distribusi sumberdaya. Di samping itu, terjadinya konflik juga disebabkan mobilisasi subordinat oleh kepemimpinan kharismatik.

Berbeda dengan Marx dan Weber, yang menjadikan unit analisisnya adalah masyarakat. Simmel menekankan unit analisis individu dalam teori konfliknya. Menurutnya bahwa salah satu tugas utama sosiologi adalah memahami interaksi antarindividu yang dapat melahirkan konflik maupun solidaritas antar sesama (Ritzer,1996: 161).

Lalu, dimanakah benang merah teori Konflik Dialektika Dahrendorf dari para tokoh penggerak teori konflik tersebut diatas. Bagan dibawah ini akan memperjelas posisi Dahrendorf : 


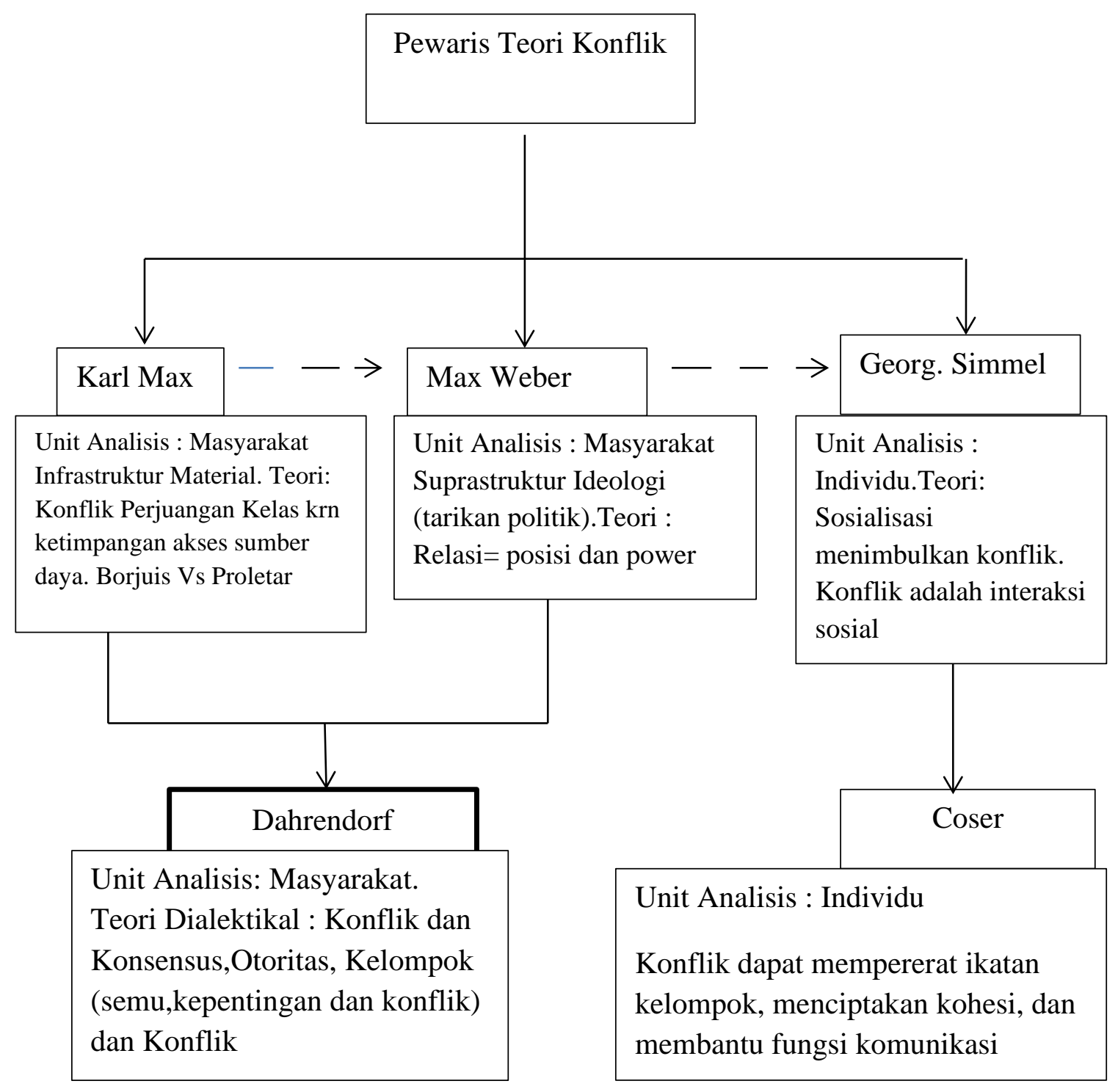

Ket : Alur pada bagan utamanya merujuk pada buku Turner (1974) : The Sructure of Sociological Theory..

Seperti terlihat dalam bagan diatas, unit analisis yang digunakan oleh Dahrendorf adalah masyarakat sebagaimana juga digunakan oleh Marx dan Weber. Namun demikian, pendekatan Marxis dan Weber lebih digunakan sebagai alat analisis saja, bahkan Dahrendorf melakukan revisi dari gagasan Karl Marx yaitu mengenai revolusi kelas, yang tidak terbukti kebenaranya dan bahwa masyarakat telah berubah menjadi struktur dari kapitalis menjadi post-kapitalis dan ini memperkuat bahwa kapitalisme belum tumbang.

Lebih lanjut, Dahrendorf menjelaskan bahwa terdapat perubahan-perubahan dalam masyarakat Industri pada abad 19 yang tidak dilihat oleh Marx. Diantara perubahan-perubahan itu 
adalah : (1) dekomposisi modal, (2) dekomposisi tenaga kerja, (3) munculnya kelas menengah baru. Dekomposisi modal dapat dilihat dari munculnya korporasi-korporasi dengan saham-saham yang dimiliki banyak orang dimana tidak seorangpun memiliki kontrol yang eksklusif. Hal yang bertentangan dengan tesis Marx yang menyebut bahwa kepemilikan dan kontol atas sarana-sarana produksi berada ditangan individu-individu yang sama (Poloma, 2013: 131).

Adapun dekomposisi tenaga kerja dapat dilihat bahwa kaum proletar tidak lagi sebagai suatu kelompok homogin yang tunggal. Pada akhir abad 19, lahir kelas pekerja dengan susunan yang jelas, dimana para buruh terampil berada di jenjang atas sedang buruh biasa berada dibawah. Kaum proletar bukan lagi sebagai massa yang tanpa perbedaan sebagaimana halnya yang terjadi pada kaum borjuis. Tukan kayu misalnya, boleh jadi dapat memperoleh gaji yang lebih besar daripada seorang operator atau nelayan (Poloma,2013: 132).

Disinilah muncul kelas baru yang disebut oleh Dahrendorf sebagai kelas menengah. Marx sendiri mengakui keberadaan kelas menengah ini pada abad ke 19. Namun menurutnya, disaat revolusi tiba, sebagian besar kelompok kecil (menengah) ini akan bergabung bersama kaum proletar untuk melawan kaum borjuis. Marx menurut Dahrendorf tidak mengamati timbulnya serikat-serikat buruh yang diikuti oleh mobilitas sosial dari para pekerja itu (Poloma,2013: 132).

Dahrendorf juga menyatakan bahwa analisa dari Karl Marx mengenai masyarkat kapitalis sebagian benar, namun untuk diterapkan pada masyarakat sekarang (Post-kapitalisme) harus dimodifikasi bahwa pengertian kelas yang mengarah pada alat produksi sudah tidak tepat tetapi lebih dijelaskan sebagai konteks kelompok-kelompok yang bertentangan disebabkan oleh pembagian wewenang didalam perserikatan yang dikoordinasi secara paksa. Ralf Dahrendorf menganalisis konflik tanpa memperhitungkan politik ekonomi yang ada (apakah kapitalisme atau sosialisme). Jika Marx bersandar pada pemilikan alat produksi, maka Dahrendorf bersandar pada kontrol atas alat produksi (Poloma,2013: 131).

Oleh karena itu, Dahrendorf membicarakan tentang konflik antara kelompok-kelompok terkoordinasi (imperatively coordinated association), dan bukan analisis perjuangan kelas, lalu tentang elit dominan, daripada pengaturan kelas, dan manajemen pekerja, daripada modal dan buruh (Zeitlin, 1998: 66).

Dalam terminologi Dahrendorf, pada masa post-kapitalisme, kepemilikan akan alat produksi (baik sosialis atau kapitalis) tidak menjamin adanya kontrol atas alat produksi. Jadi, diluar 
Marxisme, ia mengembangkan beberapa terminologi dari Max Weber, antara lain bahwa sistem sosial itu dikoordinasi secara imperatif melalui otoritas/kekuasaan.

Weber berpendapat bahwa relasi-relasi yang timbul adalah usaha-usaha untuk memperoleh posisi tinggi dalam masyarakat. Weber menekankan arti penting power (kekuasaan) dalam tipe hubungan sosial. Power (kekuasaan) merupakan penggerak dinamika sosial yang dapat memobilisasi individu dan kelompok. Namun disaat yang sama, power menjadi sumber konflik dan dalam kebanyakan kasus terjadi kombinasi kepentingan dari setiap struktur sosial sehingga menciptakan dinamika konflik (Susan,2009: 42).

Disini terlihat model perspektif konflik dialektika yang dikombinasikan dari Model Marx dan Weber. Ia percaya bahwa organisasi terbentuk dari relasi kuasa. Seperti Marx, image kelembagaan sebagai proses siklus atau dialektik memimpin Dahrendorf ke dalam analisis hubungan kasual kunci tertentu: 1) konflik diasumsikan menjadi proses yang tak terhindarkan yang timbul dari kekuatan yang berlawanan dalam pengaturan sosial dan struktural, 2) konflik tersebut dipercepat atau dihambat oleh serangkaian intervensi kondisi struktural atau variabel, 3) resolusi konflik pada satu titik waktu menciptakan situasi struktural yang, di bawah kondisi specifiable, pasti akan mengarah pada konflik lebih lanjut antara kekuatan yang berlawanan (Turner,1974: 94).

Selanjutnya Dahrendorf menekankan bahwa tugas pertama analisis konflik adalah mengidentifikasi berbagai peran otoritas di dalam masyarakat. Atau dengan kata lain, struktur sosial yang berbeda di masyarakat akan menentukan kualitas otoritas yang dimiliki oleh lapisan tertentu terhadap lapisan lainnya. Dengan demikian, secara tersirat otoritas menyatakan superordinat dan subordinat yang ada di masyarakat.

\section{E. Simpulan}

Mengambil pijakan yang sama dengan Marx dan Weber, unit analisis Daherndorf adalah masyarakat dalam skala yang luas. Mula-mula teori Konflik dilihatnya sebagai teori parsial, yang dapat dipakai untuk menganalisa fenomena sosial. Ia lebih fokus pada perubahan ketimbang ketertiban sosial (social order) yang menjadi ciri khas teori fungsionalisme. Bahkan, untuk ketertiban sosial, ia lebih menekankan pada konflik dan penggunaan kekerasan yang dilembagakan dibandingkan dengan paksaan norma-norma.

Dahrendorf melihat realitas sosial memiliki dua wajah (konflik dan konsensus). Karena itu, teori sosiologi dibagi menjadi dua bagian; teori konflik dan teori konsensus. Disini terlihat bahwa 
Daherndorf dengan teorinya berusaha menyempurnakan pendapat Marx dan Weber mengenai realitas sosial, dimana konflik yang tercipta itu disebabkan karena kepentingan yang saling bertentangan dalam struktur sosial. Kepentingan yang saling bertentangan itu merupakan refleksi dari perbedaan dalam distribusi kekuasaan antar kelompok yang superoridinat yang memiliki otoritas (mendominasi) dengan kelompok subordinat (terdominasi).Inilah tesis sentral Dahrendorf terkait realitas sosial.

Untuk mengatasi konflik yang terjadi antara superodinat dan subordinat, Dahrendorf menawarkan konsep ICA. Kekuasaan yang dihimpun dalam ICA secara dominan dapat meredam konflik. Menurutnya, suatu kepentingan yang acap kali menyebabkan konflik, bisa dinegosiasikan antar kelompok dalam ICA jika sudah menjadi kelompok kepentingan yang riil. Sehingga bergabungnya individu yang memiliki kepentingan sama dalam sebuah kelompok yang terorganisir menjadi hal yang penting.

Disinilah konsep Kelompok Semu (quasi group) dan Kelompok Kepentingan (interst group) dan Kelompok Konflik bertemu. Kelompok Semu berfungsi sebagai wadah besar bagi bersatunya tujuan yang sama dari berbagai kelompok, sebagai cikal bakal munculnya Kelompok Kepentingan. Dari Kelompok Kepentingan inilah muncul Kelompok Konflik dimana konflik yang terjadi membawa kepada perubahan.

Aspek terakhir teori konflik Dahrendorf adalah mata rantai antara konflik dan perubahan sosial. Konflik menurutnya memimpin kearah perubahan dan pembangunan. Dalam situasi konflik golongan yang terlibat melakukan tindakan-tindakan yang mengadakan perubahan dalam struktur sosial. Jika konflik itu terjadi secara hebat, maka perubahan yang timbul akan bersifat radikal. Begitu pula kalau konflik itu disertai dengan penggunaan kekerasan, maka perubahan struktural akan efektif.

\section{Daftar Pustaka}

Craib, Ian, 1992, Teori-teori Sosial Modern ; Dari Parsons Sampai Habermas, diterjemahkan oleh

Paul S Baut dan T. Effendi dari Modern Social Theory From Parsons to Habermas, Jakarta : CV Rajawali.

Dahrendrof, Ralf, 1968, Essay of The Theory of Society, USA : Stanford University press. Hakimul Ikhwan Affandi 2004, Akar Konflik Sepanjang Zaman ;Elaborasi Pemikiran IbnKhaldun, Yogyakarta : Pustaka Pelajar. 


\section{Yogi Prana Izza, Lc., MA}

Lauer, Robert H, 2001, Perspektif Tentang Perubahan Sosial, diterjemahkan oleh Alimandan S.U dari Perpective on Social Change, Jakarta : PT. Rineka Cipta.

Megawangi, Ratna 1999, Membiarkan Berbeda : Sudut Pandang baru tentang Relasi Gender, Bandung : Mizan.

Mudji, Sutrisno dan Hendar Putranto, 2005, Teori-teori Kebudayaan, Yogyakarta: Kanisius.

Nasir, Ms Nasrullah, 2009, Teori-teori Sosiologi, Bandung : Widya Padjajaran.

Poloma, Margaret, 2013, Sosiologi Kontemporer, diterjemahkan oleh Tim Penerjemah YASOGAMA dari Contemporary Sociological Theory, Jakarta :PT Raja Grafindo Persada.

Pruit, G. Dean dan Rubin, Z. Jeffery, 2004, Teori Konflik Sosial, diterjemahkan oleh Helly P.Soetjipto dan Sri Mulyantini Soetfipto dari Social Conflict ; Escalation, Stalemate, and Settlement, Yogyakarta : Pustaka Pelajar

Raho, Bernard, 2007, Teori Sosiologi Modern, Jakarta : Prestasi Pustaka.

Ritzer, George, 1996, Sociological Theory, New York : The Mc Graw-hill Companies, Inc. , 2010, Sosiologi Ilmu Pengetahuan Berparadigma Ganda, diterjemahkan oleh Alimandan dari Sociology ; A Multiple Paradigm Science, Jakarta : PT Raja Grafindo Persada.

Soerjono, Soekanto, 1990, Sosiologi Suatu Pengantar, Jakarta: PT Raja Grafindo Persada.

Susan, Novri, 2009, Sosiologi Konflik \& Isu-Isu Konflik Kontemporer, Jakarta:Kencana.

Turner,H.Jonathan, 1974, The Structure of Sociological Theory, Illionis : The Darsy Press.

Zeitlin, M. Irving 1998, Memahami Kembali Sosiologi, Yogyakarta : Gajah Mada University Press. 